\title{
Implementasi Terapi Kognitif Terhadap Kepahitan Berdasarkan Efesus 4:31-32
}

\author{
Imelda Marcos Simbolon, ${ }^{* 1}$ Mangiring Tua Togatorop, ${ }^{2}$ Daniel Ginting, ${ }^{3}$ Eko Prasetyo ${ }^{4}$ \\ Prodi Teologi, STT Real Batam \\ Prodi Teologi, STT Real Batam \\ Prodi Teologi, STT Real Batam \\ Prodi Teologi, STT Real Batam \\ imeldamarcos139@gmail.com
}

\begin{abstract}
This Curing Bitterness by using cognitive therapy based on Ephesians 4: 31 -32 is an indispensable step for recovery from deep bitter feelings. A person who saves bitterness needs to realize and admit honestly and openly that he actually suffers with the bitterness of his heart. The bitterness that is stored in a person's heart does not bring any good, but it is very detrimental to everyone who experiences it. Bitterness will result in illness spiritually and even cause physical illness. Saving bitterness will harm oneself and also harm others, because people who have bitterness in their hearts find it difficult to accept others, and even tend to think negatively of their neighbors. Paul in His writings in Ephesians 4: 31-32 emphasize that saving bitterness is not the nature of a new man who has been renewed in Christ, but it is the nature and attitude of the old man, and therefore must be discarded among Christians. The way to get rid of bitterness in the heart is by living in love and forgiveness as God has forgiven each of us. A person's knowledge and knowledge of God's truth makes him live in freedom and health both spiritually and physically.

Keywords: cognitive therapy, bitterness, love and forgiveness
\end{abstract}

\begin{abstract}
Abstrak
Menyembuhkan Kepahitan dengan menggunakan terapi kognitif berdasarkan Efesus 4: 31-32 adalah langkah yang sangat diperlukan untuk pemulihan dari rasa pahit yang mendalam. Seorang yang menyimpan kepahitan perlu menyadari dan mengaku dengan jujur dan terbuka bahwa sebenarnya ia menderita dengan kepahitan hati yang ia alami. Kepahitan yang tersimpan dalam hati seseorang, sedikitpun tidak membawa kepada kebaikan, tetapi justru sangat merugikan setiap orang yang mengalaminya. Kepahitan akan mengakibatkan penyakit secara rohani bahkan juga mengakibatkan penyakit secara jasmani. Menyimpan kepahitan akan merugikan diri sendiri dan juga merugikan orang lain, sebab orang yang penyimpan kepahitan hati sulit menerima orang lain, bahkan cenderung berfikir negatif kepada sesamanya. Paulus dalam Tulisannya dalam Efesus 4:31-32 mempertegas bahwa menyimpan kepahitan bukanlah sifat dari dari seorang manusia baru yang telah dibaharui dalam Kristus, tetapi itu adalah sifat dan sikap dari manusia lama, oleh karenanya harus dibuang diantara orang Kristen. Cara untuk membuang kepahitan dalam hati adalah dengan cara hidup di dalam kasih dan pengampunan seperti Allah telah mengampuni setiap kita. Pengetahuan dan peneganalan seseorang akan kebenaran Allah menjadikan dia hidup dalam kebebasan dan kesehatan baik secara rohani maupun secara fisik.

Kata kunci: Terapi kognitif, Kepahitan, Kasih dan Pengampunan
\end{abstract}




\section{PENDAHULUAN}

Kepahitan atau sering disebut sebagai luka batin merupakan satu perasaan atau sifat yang harus dijauhkan dari dupan kekristenan. Paulus jelaskan dalam Efesus 4:30-31, bahwa setiap mereka yang telah dibaharui oleh Kristus, harus membuang jauh jauh perasaan pahit atau geram dan amarah, sebab hal itu bukanlah padanan kehidupan yang baru. Kristian Siregar mengungkapkan bahwa kepahitan dan luka batin merupaan akibat dari pengalaman masa lalu seseorang atau pengalaman mengecewakan dan menyakitan yang dialami, sehingga berunjung pada kepahitan dan luka batin. ${ }^{1}$ Dicermati dari penryataan di atas bahwa rasa pahit diakibatkan dari rasa kecewa atau pengalaman pahit yang dialami, maka kepahitan berpotensi dialami oleh setiap orang Kristen, itu sebabnya Paulus berkata harus dibuang dari antara orang Kristen. Kepahitan hati pada umumnya berwujud pada kebencian yang sangat mendalam, dimana hal ini ditandai oleh sikap yang sinis dan tertutup serta amarah dalam diri. Gunawan mengungkapkan bahwa luka batin atau kepahitan yang dialami oleh seseorang akan mempengaruhi seluruh kehidupannya baik dalam sikap, ekspresi dan tindakan, baik yang menyangkut hubunganya dengan orang lain maupun dengan dirinya sendiri. ${ }^{2}$

Alkitab tidak melarang kita merasa tidak senang, namun memberi dua pembatas. Pertama, marah harus bebas dari kepahitan, dendam dan benci. Kedua, menguji diri tiap hari agar diri agar tidak dikuasi oleh rasa dengki. Sebuah pepatah latin mengatakan: ' 'orang yang tidur menyimpan rasa marah, tidur dengan iblis." Tentu hidup banyak gangguan. Hal sepeti inilah yang dimanfaatkan iblis untuk membangkitkan jahat pada diri sesorang. Perasaan-perasaan yang terpendam memakan habis diri orang, sampai emosinya lumpuh dan tubuhnya sakit. Daya berfungsinya terganggu, kegunaanya merosot akan mengakibatkan orang yang kepahitan akan cenderung sukar tidur dan hubunganhubunganya di dalam dan di luar keluarga, terkikis. Sebagian orang yang mengalami kepahitan cenderung dikuasai oleh keinginan membalas dendam, sampai kepada keinginan membunuh orang yang dibencinya. Orang yang menyimpan endapan rasa marah yang tidak terselaikan, disebutkan oleh Rasul Paulus bukan orang yang sehat rohani, bahkan juga jasmani. Dalam artikel jawaban.com yang mengutip hasil penelitian dari Universitas Concordia yang mengungkapkan bahwa Kepahitan yang dialami atau dipendam oleh seseorang bisa menjadi sumber penyakit bagi dirinya sendiri. ${ }^{3}$ Artinya kepahitan tidak hanya menjadi masalah bagi kesehatan dan pertumbuhan rohani tetapi juga menjadi masalah bagi kesehatan secara fisik, itu sebabnya tidak perlu menyimpan kepahitan tetapi harus dibuang. "Seorang psikolog bernama Carsten Wrosch mengungkapkan bahwa seseorang yang mengalami Kepahitan terus menerus bisa menyebabkan perasaan marah

\footnotetext{
${ }^{1}$ Christian Siregar, “Menyembuhkan Luka Batin Dengan Memaafkan,” Humaniora 3, no. 2 (2012): 581.

${ }^{2}$ Agung Gunawan, "Implikasi Kebangkitan Kristus Bagi Pemulihan Luka Batin Dalam Pelayanan Pastoral," Jurnal Teologi Alitteia, 08 no. 2 (2006): 3-18.

${ }^{3}$ https://www.jawaban.com/read/article/id, "Kepahitan sama seseorang bisa jadi sumber penyakit."
} 
dan permusuhan yang meluas kepada orang lain jika tidak segera ditandani dan disembuhkan. ${ }^{4}$

Sebaliknya Alkitab menjelaskan bahwa "hati yang gembira (bebas dari kepahitan) membuat muka berseri-seri, tetapi kepedihan hati mematahkan semangat." (Amsal 15:13). Selanjutnya penulis Amsal berkata bahwa "hati yang gembira adalah obat yang manjur." (Amsal 17:22). Artinya bahwa hati yang gembira menjadi obat yang menyegarkan jiwa dan fisik seseorang. Kisah Kain dalam kitab Kejadian 4:1-16 menjelaskan bagi kita bahwa kepahitan dan amarah membuahkan tindakan yang tidak terpuji, dimana oleh amarahnya Kain membunuh adiknya Habel. Paulus menjelaskan bahwa kepahitan, geram dan amarah hanya bisa disembuhkan lewat kasih mesra, pengampunan yang tanpa batas seperti Allah telah mengampuni setiap manusia berdosa (Efesus 4:31). Artinya lewat pengenalan dan pengetahuan akan kebenaran seseorang bisa terbebas dari rasa pahit hati atau dendam. Paulus berkata, bahwa kamu telah mendengar tentang Dia dan telah menerima kebenaran yang nyata di dalam Yesus, oleh karenanya hiduplah dalam kehidupan yang baru supaya roh dan pikiranmu dibaharui dan mengenakan manusia baru yang penuh dengan kasih dan pengampunan serta hidup dalam kebenaran yang memerdekakan.

\section{METODE}

Metode yang digunakan dalam penelitian ini dengan menggunakan metode kualitatif yang menekankan aspek mendalam terhadap suatu permasalahan dengan teknik analisis mendalam dalam memahami permasalahan kepahitan dengan mengimplementasikan terapi kognitif.

\section{HASIL DAN PEMBAHASAN}

Istilah Ada kalanya seseorang bisa mengampuni, tetapi tak jarang ada banyak orang justru menyimpan kepahitan bertahun-tahun lamanya. Akibat kepahitan itu awalnya tidak terasa, tetapi lama-kelamaan dia menyebar bagaikan racun yang merusak sendi-sendi semua kehidupan orang yang mengalaminya. Tidak sedikit orang Kristen yang salah memahami tentang menyimpan kepahitan (tidak segera memberi pengampunan) dengan tujuan mau memberi sedikit hukuman kepada orang yang melukainya tersebut akan tetapi justru ini menjadi bahaya besar bagi dirinya sendiri, sebab ia menciptakan situasi tidak nyaman dalam hidupnya sendiri. Julianto Simanjuntak mengungkapkan bahwa sesungguhnya menunda pengampunan terhadap seseorang yang melukai ataumenyakiti adalah sebuah balas dendam yang halus dimana hal ini bertentangan dengan kebenaran. ${ }^{5}$ Kepahitan adalah virus yang mematikan bagi jiwa setiap orang yang mengalaminya, ironisnya perasaan ini umumnya tidak disadari oleh sebagian orang. Tiba-tiba virus ini menggerogoti seluruh hidup orang yang memeliharanya. Peristiwa-peristiwa negatif yang sering dialami oleh seseorang seringkali meninggalkan luka dalam yang luar biasa,

\footnotetext{
${ }^{4}$ Ibid.

${ }^{5}$ Julianto Simanjuntak, Mencintai Hingga Terluka (Jakarta: IKAPI, 2009). Hal. 5
} 
sehingga sulit ia hidup dalam kelegaan, sebab kepahitan mengikat dirinya sehingga hidup dalam kegelisahan dan ketidak nyamanan.

Gunawan mengungkapkan bahwa aspek aspek yang bisa membawa seseorang kepada kepahitan dan luka batin apabila ia mengalami pengalaman yang tidak semestetninya seperti pekecehan secara fisik seperti pemukulan, pelecahan secara emosi seperti disakiti, ditolak, pelecehan secara seksual seperti pemerkosaan dan pelecehan secara spiritual seperti dihakimi oleh karena dosa tertentu serta pelecehan lainya yang menyakitkan bagi seseorang. ${ }^{6}$

Keadaan hati yang pahit atau sering disebut sebagai luka batin jika tidak diatasi dengan benar, hal ini dapat menimbulkan akar pahit yang bisa merusak kesehatan mental dan fisik, juga spritualitas. Kepahitan lebih dari sekedar pandangan negatip terhadap hidup. Kepahitan merupakan kekuatan yang merusak relasi dengan siapapun, tetapi terutama mengahancurkan diri sendiri. Orang yang terluka dan punya akar pahit cenderung menyendiri karena merasa tidak dapat mempercayai orang lain, cenderung posesif dan manipulative oleh karena ia merasa tidak nyaman kepada siapapun. Ia menjadi satu pribadi yang sulit diajar atau dikritik, sebaliknya suka mengkritik orang lain bahkan ada kecendrungan menghakimi orang lain oleh karena mengukurnya dari pikiran dan jiwanya yang masih dalam kepahitan.

Orang yang kepahitan pada umumnya sakit hati, sinis,kasar,dingin dan tidak menyenangkan. Ekspresi sifat-sifat ini adalah dosa terhadap Allah. Ibrani 12:15 menghimbau kita: " jagalah supaya jangan ada seorangpun menjauhkan diri dari kasih karunia Allah, akar jangan tumbuh akar pahit yang menimbukan kerusuhan dan mencemarkan banyak orang. Alkitab mengatakan Matius 15:19-20, "'karena dari hati timbul segala pikiran jahat, pembunuhan, perzinahan, percabulan, pencurian, sumpah palsu dan hujat. Itulah yang menajiskan orang. Tetapi makan dengan tangan yang tak dibasuh tidak menajiskan orang', Dengan kata lain, kalau memiliki kepahitan akan mengontaminasi pribadi dan sikap seseorang.

Charles. R. Gerber mengungkapkan dalam bukunya bahwa kepahitan dapat disebabkan oleh tiga bagian peristiw penting yaitu dukacita, ketidakadilan dan penghianatan yang dialami oleh seseorang. ${ }^{7}$ Kehilangan seseorang yang sangat dicintai merupakan suatu pukulan yang sangat besar bagi sebagian besar orang. Hal inilah yang akan menyebabkan trauma kehilangan memberikan luka yang membekas; akan tetapi bisa saja luka itu yang seloh sembuh dapat kambuh kembali menjadi sangat sakit. Perasaan kehilangan itu merupakan pengalaman yang negatif yang menggelisakan yang dapat menggejala secara physically, emotionally, cognitively, socially, maupum spiritual. Segaa bentuk kehilangan pasti akan menimbukan rasa dukacita baik itu secara biasa ataupun

\footnotetext{
${ }^{6}$ Agung Gunawan, "Implikasi Kebangkitan Kristus Bagi Pemulihan Luka Batin Dalam Pelayanan Pastoral."hal. 5-6

${ }^{7}$ Charles R. Gerber, Kesembuhan Untuk Kepahitan Hati (Jakarta, 2017).
} 
mendalam dan menimbulkan gejala-gejala yaitu peresaan ragu-ragu, kehilangan kepercayaan, lemahnya vitalitas rohan, rasa sedih dan juga perasaan jiwa yang kosong.

Alkitab banyak memberikan banyak kesaksian tentang dukacita. Allah sebagai gembala yang baik menjanjikan penyertaan untuk setiap anak-anakNya yang lembah kekelaman dan dukacita (Mzm 23:24). Kehilangan banyaknhal baik dimasa kanak-kanak akan membuat identitas anak menjadi abu-abu, membuat harga diri mereka jatuh dan merasa diri tidak berarti sehinggah timbullah hal-hal seperti: sensitif, tidak percaya diri, sulit mempercayai orang lain, mudah merasa cemas dan mudah tersinggung.

Didalam aspek apapun dalam kehidupan manusia pasti pernah mengalami ketidakadilan. Untuk sebagian orang melihat hal ini secara sepele namun dalam kenyataanya ketidakadilan terjadi ketika seseorang tidak mendapat sesuatu yang harus nya menjadi milikna/haknya. Yang secara umum banyak terjadi adalah dalam keluarga, misalnya; anak yang paling bungsu biasanya akan lebih mendapakan kasih sayang lebih dari orangtua dibandingkan dengan anak yang sulung atau saudranya yang lain.

Penghianatan juga merupakan faktor penyebab kepahitan. Penghiatan terjadi karena adanya pembohongan, kepura-puraan dalam mencintai seseorang, pengingkaran janji. Contoh seseorang yang pahit akibat penghianatan adalah seorang wanita yang ditinggalkan laki-laki. Rasa sakit inilah yang menjadi berubah menjadi sikap tidak mau mengampuni yang sudah lama dan kenal ampun. Terkadang,orang seperti ini akan memperjuangkan penyebab kepahitan dalam diri wanita. Mereka mungkin tetap belum menikah selama sisah hiduo mereka. Bahkan bisa berkembang dan merosot lebih jauh ke lesbianisme. Para lesbias seringkali adalah wanita kepahitan; pahit hati trhadap pria yang mungkin menyakitimereka dalam hidup mereka. ${ }^{8}$

\section{Akibat Kepahitan}

Secara tubuh, jika seseorang kepahitan maka akan menimbulkan berbagai macam penyakit ( amsal 14:30) hati yang tenang menyegarkan tubuh, tetapi iri hari membusukkan tulang. Dan dalam amsal 17:22 hati yang gembira adala obat yang manjur, tetapi semangat yagng patah mengeringkan tulang. Artinya membuat wajah tidak berseri-seri , merasakan bahwa tidak adalagi pengharapan yang bisa diraih.

Sedangkan secara rohani kepahitan akan menyebabkan seseorang sulit untuk berdoa kepada Tuhan. Kepahitan juga berdampak pada mental seseorang. Orang yang kepahitan tidak akan dapat mengasihi Tuhan dengan sungguh-sungguh. Dan tidak akan pernah menyadari bahwa dirinya sangat berharga. Hal ini akan menyebabkan rencana Tuhan tidak akan sampai keatas hidupnya secara sempurnah. Orang yang kepahitan akan cenderung sukar melihat segala sesuatu yang unik yang Tuhan sedang kerjakan terhadapnya. Menimbulkan pertanyaan-pertanyaan kenapa, kenapa dan kenapa, dalam arti lain tidak mampu untuk mengucap syukur. Orang yang kepahitan akan merasakan harapan

\footnotetext{
${ }^{8}$ Mills Dag Hewars, Pengampunan Menjadi Mudah (Lux Verbi BM, 2017). Hal. 4
} 
yang hilang. Karena harapan hilang terjadi karena ketika seseorang tidak memiliki tujuan hidup yang jelas dan merasakan buat apa hidup ini dan biasanya dampak akhirnya adalah keputusasaan atau depresi yang sangat kuat.

\section{Terapi Kognitif Konseling Kepahitan}

Menurut Albert Ellis, manusia menjadi korban indoktrinasi untuk berfikir secara irrasioal tentang dirinya sejak masa kanak-kanaknya. Bila orang tidak memiliki cara berfikir yang sehat maka ia menunjukkan tingkah laku yang merugikan. Pikiran adalah sumber kekuatan, sebab apa yang dipikikrkan tu juga yang dirasakan, dan itu juga yang dikerjakan. Jadi cara berfikir yang sehat adalah kunci tingkah laku yang baik. Dengan mengubah cara berfikir secara positif yakni berfikir rasional, mak pengalaman masa lalu yang tidak menguntungkan dapat diatasi. Ellis memperkenalkan teori psikologi yang terkait dengan cara berikir dan perasaan saling berhubungan, namun pendekatannya lebih dititik beratkan pada pikiran (ratio) ketimbang paa emosi seseorang. ${ }^{9}$ Jadi, konselor berusaha memperbaiki yang bersangkutan melalui pola pikir yang positif dan menghilangkan cara berfikir irasional yaitu berfikir negative atau tidak benar. Dengan cara ini terjadi 'reeducation'" (mendidik kembali) agar berfikir positif, sebab pikiran manusia sangat mempengaruhi tindakan-tindakan manusia.

\section{Tiga Langkah Pendekatan konseling yang ditempuh:}

1. Konselor memberi tahu cara befikir irrasional (tidak logis) lalu mengajak konseli keluar dari cara berpikir demikian. Konseli diajar membedakan hal-hal yang rasional dan positif dengan hal-hal yang tidak rasional dan berfikir negative.

2. Pola berpikir irasional harus ditinggalkan konseli sebab cara berfikir yang demikian hanya membuat dirinya terganggu dan menderita.

3. Dalam rangka meninggalkan cara berpikir irasional dan negative, konselor memakai pendekatan yang langsung (directive), agar konseli meninggalkan 'pita cara berpikir irasional dan negatif' tersebut dan menggantikannya dengan cara berpikir rasional/logis dan berpikir positif.

\section{Terapan Terapi Cognitive Melalui Kasih Yesus Memulihkan Kepahitan}

Dalam Mazmur 107:1 mengatakan 'Bersyukurlah kepada TUHAN, sebab Ia baik! Bahwasanya untuk selama-lamanya kasih setia-Nya."

Hal membuktikan bahwa Tuhan itu baik, kasih setianya bukan hanya untuk hari ini, esok akan tetapi hari ini sampai selama-lamanya. Yesus sangat mengasihi kita terbukti dia menebus kita dengan darahNya. Karena kita tidak baik, maka kita punya Tuhan yang baik yang memberikan teladan kepada kita untuk kita sanggup memberikan hal yang terbaik juga kepada orang lain. Jadi tidak ada dasar untuk kita tidak dapat melihat kebaikan Tuhan.

\footnotetext{
${ }^{9}$ E.P. Ginting, Konseling Pastoral (Jakarta: IKAPI, 2009).
} 
Matius 26:28, "Sebab inilah darah-Ku, darah perjanjian, yang ditumpahkan bagi banyak orang untuk pengampunan dosa". Yesus mencurahkan darah-Nya untuk kita supaya kita memperoleh pengampunan. Saat kita menyadari pengorbanan Yesus ini, kita juga harus melakukan tindakan yang kepada orang lain. Yesus mengorbankan darah-Nya supaya kita memperoleh akses kepada kasih Bapa. Kolose 3:13 juga mengatakan "Sabarlah kamu seorang terhadap yang lain, dan ampunilah seorang akan yang lain apabila yang seorang menaruh dendam terhadap yang lain, sama seperti Tuhan telah mengampuni kamu, kamu perbuat jugalah demikian. Mengampuni artinya saling menanggung beban satu sama lain. Gak semua orang akan berubah setelah menerima pengampunan.Jadi untuk orang-orang seperti ini, kita perlu menanggung dosanya sampai dia benar-benar berubah. Seperti itulah Tuhan lakukan atas kita, kita harus menunjukkan kesabaran, menunggu orang yang bersalah berubah dan mengampuni dia saat dia kembali melakukan kesalahan.

Yesus menerima setiap orang yang berdosa. Yesus tidak menghakim, menyalahkan bahkan yang dilakukan Yesus adalah Dia menerima orang berdosa. Hal ini dapat dilihat ketika Yesus bertemu dengan perempuan yang kedapatan berzinah (Yoh 8:1-11). Yesus tidak mengkiminya, tidak mengingat-ngingat kesalahannya, yang dikatakan Yesus kepada perempuan itu untuk pergi dan jangan berbuat dosa lagi. Begitu pun dengan kita, ketika berdosa Tuhan tidak pernah menghukum bahkan mengahakimi akan tetapi Tuhan menerima apa adanya asalkan kita berbalik dari dosa itu dan tidak berbuat dosa lagi.

Yesus mengasihi setiap manusia tanpa terkecuali. Bukti Yesus mengasihi kita, 1 Petrus 1:18-19 mengatakan bahwa kita semua ditebus dengan cara hidup kita yang sia-sia dengan membayarnya dengan sangat mahal yaitu darah Yesus sendiri. Pengorbanan Yesus dikayu salib merupakan satu anugrah terbesar bahwa Yesus terbukti mengasihi kita.

\section{Siapa Yang Tidak Pernah Salah}

Semua manusia pernah berbuat salah, tidak ada satupun manusia didunia ini yang tidak pernah melakukan kesalahan. Kesalahan yang disengaja maupun kesalahan yang mungkin terjadi tanpa diluar kendali kita. Setiap manusia adalah seorang yang berdosa. Namun, kuasa dosa sudah dikalahkan darahNya, sekaran manusia dapat ditebus dari dosadosa mereka. Dalam keadaan seperti ini pemulihan, dengan mengakui kesalahan. Ada dua macam pengampunan Tuhan. yang pertama adalah pengampunan secara hukum, yaitu penebusan dosa secara tuntas oleh Kristus, yang menjamin kita bebas dari hukuman dosa dan menjadi anak Allah. Dan yang kedua adalah pengampunan sebagai keluarga, yaitu pemulihan relasi dan persekuaan dengan Tuhan setelah kita mengakui dosa yang kita lakukan sebagai anak-Nya yang sudah ditebus. ${ }^{10}$

Inti dari masalah ini adalah bahwa pengampunan dari orang lain bisa menjadi nyata dalam hidup kita hanya bila kita mau mengampuni diri kita sendiri. Bila memikul beban rasa bersalah karena belum mengampuni diri sendiri, mungkin inilah saatnya untuk

\footnotetext{
${ }^{10}$ Berakar Dalam Kristus - Pemuridan Melalui Waktu Teduh (Yogyakarta: Yayasan Glorya, 2011).
} 
menerima pengampunan dari Allah dan mulai hidup baru!. Dengan kata lain, menerima pengampunan sama dengan memulihkan kembali, memampukan kita hidup sebagaimana harusnya kita hidup'. Pada akhirnya, mengampuni diri sendiri berujung pada iman. Iman dalam kekuatan pengampunan. Iman didalam Allah memancarkan kasih.

"Siapakah Allah seperti engkau yang mengampuni dosa, dan yang memaafkan pelanggaran dari sisa-sisa milikNya sendiri; yang tidak bertahan dalam murkaNya untuk seterusnya, melainkan berkenan kepada kasih setia?' (Mikha 7:18). Bila tidak mempunyai iman itu, hal yang bisa kita lakukan adalah berdoa meminta kepada Tuhan dan juga bisa mengajak orang lain, khususnya mereka yang "memiliki'" iman itu, untuk berdoa bersama dengan anda. Bila ada seseorang yang kita kenal tidak memiliki iman itu, konseli bisa berdoa agar dibebaskan dari siksaan dan keraguan sehinggah dia mengenal kedamaian yang melebihi pemahaman. $^{11}$

\section{Kepahitan Berdasarkan Efesus 4: 31-32}

Pengampunan merupakan suatu hal yang paling penting dalam kehidupan orangorang Kristen. Orang-orang berdosa diselamatkan oleh karena pengampunan yang Allah berikan kepada setiap manusia. Yesus pun dalam pengajaran-Nya (Mat. 6:14-15) mengajarkan murid-murid-Nya untuk dapat mengampuni seperti Kristus mengampuni. Bahkan melalui suratnya kepada jemaat di Efesus dalam Efesus 4:31-32, Paulus mengingatkan mereka untuk membuang segala kepahitan, kegeraman, kemarahan, pertikaian, fitnah, dan kejahatan. Tidak hanya itu, Paulus menginginkan jemaatnya untuk dapat ramah seorang dengan yang lain, penuh kasih mesra, dan saling mengampuni seperti Kristus telah mengampuni.

Pada konteks sebelumnya Paulus, memberikan penegasan kembali tentang apa yang tidak boleh dilakukan oleh manusia baru. Dikatakan demikian 'Kepahitan, Kegeraman, kemarahan, pertikaian, dan Fitnah. Paulus sedang menujuk kepada tindakan-tindakan yang dilakukan oleh jemaat Efesus pada saat mereka percaya, yang seharusnya tidak dilakukan. Disinilah Paulus memberikan ketegasan kepada mereka untuk meninggalkan semua itu. Jika kita meninjau pada konteks sesudah ini pada Ayat pertama di dalam pasal ke 5 Paulus mengajarkan kepatuhan kepada jemaat. dimana jemaat diajarkan arti dari sebuah keyakinan dan kesetian. ' dikatakan demikian 'jadilah penurut-penurut Allah, seperti anak-anak yang kekasih. Paulus berbicara kedekatan secara dalam antara kehidupan yang dilakukan anak dan Ayah, Dengan demikian bisa dikatakan sebagai orang percaya yang terkasih didalam kepatuhan yang dalam. Perintah Yang benar 'Tetapi hendaklah kamu ramah seorang terhadap yang lain,' Pada ayat 32 bagian (a) ini, dimana Paulus memberikan perintah yang bersifat ajakan kepada jemaatnya, dengan mengatakan demikian. Tetapi hendaklah, 'jika kita mencermati kata 'Tetapi' yang diungkapkan oleh Paulus adalah kata sambung dari kata sebelumnya. Kata 'Tetapi' memiliki makna penting bagi jemaat. Dimana Paulus sedang

${ }^{11}$ Dorris Nonnelly, Putting Forgive Into Practise (Texas: Argus Communication, 1982). 
mengarahkan pada paradigma berpikir, tentang kekristenan yang di jalankan oleh jemaat di Efesus. Kata 'Tetapi' memberikan satu arahan yang jelas akan tindakan selanjutnya. Pada bagian sebelumnya dimana Paulus telah memberikan pemaparan yang konkrit atas apa yang salah yang telah dilakukan oleh jemaat Efesus. Paulus memberikan sesuatu paradigma yang baru kepada jemaat tentang mengikuti Yesus.

Pada bagian selanjutnya kata 'Hendaklah' memberikan arahan yang jelas kepada jemaat yang seharusnya mereka lakukan sebagai orang percaya. Kata 'Hendaklah' dalam (KBI) diartikan adalah mau; akan; bermaksud akan' ini menujukan kepada Jemaat, apa yang dimaksudkan Paulus, agar jemaat dapat melakukan yang baik. Hal ini bisa kita lihat kata 'ramah' aslinya memakai kata $\chi \rho \eta \sigma \tau o ́ \varsigma$ (chrestos) menujuk kepada 'baik hati atau penuh belas kasih' terhadap orang lain. Paulus mengajarkan kembali ajaran Yesus tentang hukum kedua 'Matius 22:39 Dan hukum yang kedua, yang sama dengan itu, ialah: Kasihilah sesamamu manusia seperti dirimu sendiri. Paulus mengarahkan kasih yang tulus kepada orang lain tanpa imbalan hal ini kita bisa melihat pada bagian poin kedua, yang ditekankan oleh Paulus. Bentuk Perintah Yang Benar ' penuh kasih mesra dan saling mengampuni,' Pada poin yang kedua ini kita bisa melihat dari perintah ajaran yang benar, yang Paulus tekankan pada jemaat. Kita bisa melihat dari kata 'penuh dan Mengampuni' dua kata ini menunjuk kepada sebuah tindakan yang seharusnya dilakukan orang yang telah percaya kepada Yesus.

Pada bagian pertama, kata penuh kasih mesra. Paulus sedang mengajarkan kasih mesra yang harus dilakukan oleh setiap orang percaya harus sampai penuh atau terus terisi walau sudah ada. Sehingga kasih mesra orang percaya terlihat dan terpancar kepada banyak orang, hal ini sinergi dengan (Mat 5:16). Selanjutnya adalah kata 'pengampunan' kata pengampunan itu ditekankan oleh Paulus dikarenakan jemaat ini, sangat sulit untuk mengampuni hal itu terlihat dari konteks sebelumnya yang dijabarkan oleh paulus pada (ayat 31).

Kata pengampunan sendiri menggunakan kata $\chi \alpha$ í $_{0} \mu_{\alpha \iota}$ charizomai mengampuni atau melepaskan memperlakukan dengan murah hati' . Menunjuk kepada sikap yang mau sungguh-sungguh mengampuni kesalahan orang lain. Disinilah kekuatan kasih yang ditunjukkan oleh ajaran kekristenan itu sendiri. Paulus menempatkan dua porsi dasar ajaran yang benar, dimana belas kasih itu terlihat yang bisa nampak dari sikap hati yang mau mengampuni kesalahan orang lain. Maka kekristenan sejati akan benar-benar terlihat wujud nyata bagi orang lain dalam konteks tersebut adalah orang-orang kafir yang ada di Efesus. Teladan Yang Benar ' sebagaimana Allah di dalam Kristus telah mengampuni kamu.' Pada bagian yang terakhir Paulus mengajarkan landasan yang benar atas apa yang telah diajarkan oleh Paulus.. Tidak karena pengampunan yang murni akan keluar dimana Roh Kudus itu memampukan setiap orang percaya. Sehingga pengampunan yang digambarkan Paulus melalui diri Allah di dalam Yesus Kristus tidaklah berat untuk dilakukan oleh setiap 
orang Percaya dimana, setiap orang percaya dikuatkan dan dimampukan oleh Roh Kudus yang Allah sendiri berikan.

\section{KESIMPULAN}

Kepahitan yang tersimpan dalam hati seseorang, sedikitpun tidak membawa kepada kebaikan, tetapi justru sangat merugikan setiap orang yang mengalaminya. Kepahitan akan mengakibatkan penyakit secara rohani bahkan juga mengakibatkan penyakit secara jasmani. Menyimpan kepahitan akan merugikan diri sendiri dan juga merugikan orang lain, sebab orang yang penyimpan kepahitan hati sulit menerima orang lain, bahkan cenderung berfikir negatif kepada sesamanya.

Paulus dalam Tulisannya dalam Efesus 4:31-32 mempertegas bahwa menyimpan kepahitan bukanlah sifat dari dari seorang manusia baru yang telah dibaharui dalam Kristus, tetapi itu adalah sifat dan sikap dari manusia lama, oleh karenanya harus dibuang diantara orang Kristen. Cara untuk membuang kepahitan dalam hati adalah dengan cara hidup di dalam kasih dan pengampunan seperti Allah telah mengampuni setiap kita. Pengetahuan dan peneganalan seseorang akan kebenaran Allah menjadikan dia hidup dalam kebebasan dan kesehatan baik secara rohani maupun secara fisik.

\section{KEPUSTAKAAN}

Agung Gunawan. "Implikasi Kebangkitan Kristus Bagi Pemulihan Luka Batin Dalam Pelayanan Pastoral.” Jurnal Teologi Alitteia, 08 no. 2 (2006): 3-18.

Charles R. Gerber. Kesembuhan Untuk Kepahitan Hati. Jakarta, 2017.

Dorris Nonnelly. Putting Forgive Into Practise. Texas: Argus Communication, 1982.

E.P. Ginting. Konseling Pastoral. Jakarta: IKAPI, 2009.

https://www.jawaban.com/read/article/id.

"Kepahitan_sama_seseorang_bisa_jadi_sumber_penyakit."

Julianto Simanjuntak. Mencintai Hingga Terluka. Jakarta: IKAPI, 2009.

Mills Dag Hewars. Pengampunan Menjadi Mudah. Lux Verbi BM, 2017.

Siregar, Christian. "Menyembuhkan Luka Batin Dengan Memaafkan.” Humaniora 3, no. 2 (2012): 581.

Berakar Dalam Kristus - Pemuridan Melalui Waktu Teduh. Yogyakarta: Yayasan Glorya, 2011. 